\title{
PERLINDUNGAN HUKUM BAGI DOKTER PADA PELAYANAN KEGAWATDARURATAN DI RUMAH SAKIT UMUM DAERAH ABDUL WAHAB SJAHRANIE SAMARINDA
}

\author{
Anton Christian Ompu Sunggu \\ Magister Hukum Fakultas Hukum Universitas Jenderal Soedirman
}

\begin{abstract}
The Research purpose to analyze the implementation of law protection for doctors in the emergency service unit at the Abdul Wahab Sjahranie Samarinda and to analyze the solutions applied by the emergency unit to resolve the issues regarding to the law protection. Research methodology uses the 'yuridis normatif' approach where the research type to find law 'in concreto'. The research is conducted at the Abdul Wahab Sjahranie Hospital in Samarinda.

Based on the research results, the implementation of law protection for doctros in the emergency unit at the Abdul Wahab Sjahranie Samarinda has been applied according to the Law and Regulation in Indonesia therefore the doctors have practiced the medical actions following the standard operational procedures (SOP). In this case, they are not able to be prosecuted in the event of mistreatment and to resolve the medical dispute, the hospital employs the mediation process called Alternative Dispute Resolution (ADR) according to Articles No. 36 Year 2009 about health chapter 29 that states in the event of negligence by doctors in conducting medical actions, is able to be settled by mediation.
\end{abstract}

Key words : Alternative Dispute Resolution, emergency.

\begin{abstract}
Abstrak
Penelitian ini bertujuan untuk menganalisis cara penerapan perlindungan hukum bagi dokter dan cara penyelesaian permasalahan yang dipakai pada pelayanan kegawat daruratan di Rumah Sakit Umum Daerah Abdul Wahab Sjahranie Samarinda.

Metode penelitian yang digunakan dengan pendekatan yuridis normatif sedangkan tipe penelitiannya untuk menemukan hukum in concreto. Sumber data yang digunakan dalam penelitian adalah sumber data sekunder hasil dokumentasi bagian medikolegal Rumah Sakit Umum Daerah Abdul Wahab Sjahranie Samarinda.

Berdasarkan hasil penelitian dan pembahasan yang diajukan dalam tesis ini, maka dapat disimpulkan upaya penerapan perlindungan hukum bagi dokter pada pelayanan kegawat daruratan di Rumah Sakit Umum Abdul Wahab Sjahranie samarinda sudah sesuai menurut perundang-undangan dan peraturan yang berlaku saat ini di Indonesia sehingga bagi dokter pada pelayanan kegawat daruratan yang telah melakukan tindakan medik yang sesuai dengan standar profesi dan standar operational procedure (SOP) maka tidak patut untuk dipersalahkan dan mengenai cara penyelesaian sengketa medis pada pelayanan kegawat daruratan di Rumah Sakit Umum Abdul Wahab Sjahranie menggunakan proses mediasi yang termasuk dalam Alternative Dispute Resolution (ADR) yang telah sesuai menurut Undang- Undang Nomor 36 Tahun 2009 tentang Kesehatan Pasal 29 yang menyatakan bahwa dalam hal tenaga kesehatan diduga melakukan kelalaian dalam menjalankan profesinya, kelalaian tersebut harus diselesaikan terlebih dahulu melalui mediasi.

Kata kunci : Alternative Dispute Resolution, kegawatdaruratan.

\section{PENDAHULUAN}

Indonesia adalah negara hukum

(rechtstaat). Landasan ini tertuang dalam Undang-

undang Dasar 1945 Pasal 1 Angka 3, yang

menyatakan bahwa "Segala warganegara bersamaan kedudukannya di dalam Hukum dan Pemerintahan dan wajib menjunjung Hukum dan Pemerintahan itu dengan tidak ada kecualinya".
\end{abstract}


Hubungan dokter dengan pasien juga kalau dilihat dari kacamata hukum, merupakan hubungan hukum, karena hubungan dokter dengan pasien telah diatur dalam Undang-undang Nomor 29 Tahun 2004 tentang Praktik Kedokteran.

Informed consent dalam pelayanan kesehatan, telah memperoleh pembenaran secara yuridis melalui Peraturan Menteri Kesehatan Republik Indonesia Nomor.290 Tahun 2008 tentang Persetujuan Tindakan Kedokteran dan terdapat pula pada Pasal 39, 45 dari Undangundang Nomor 29 Tahun 2004 tentang Praktik Kedokteran yang menyatakan bahwa, praktik kedokteran diselenggarakan berdasarkan pada kesepakatan antara dokter dengan pasien dalam upaya untuk pemeliharaan, pencegahan penyakit, peningkatan kesehatan, pengobatan penyakit dan pemulihan kesehatan. Segala tindakan medik yang dilakukan akan dilakukan dokter harus mendapatkan persetujuan pasien. Walaupun dalam kenyataannya untuk pelaksanaan pemberian informasi guna mendapatkan persetujuan itu tidak sesederhana yang dibayangkan, namun setidak-tidaknya persoalannya telah diatur secara hukum, sehingga ada kekuatan hukum bagi kedua belah pihak untuk melakukan tindakan secara hukum. ${ }^{1}$

Kejadian gawat darurat dapat terjadi kapan saja, dimana saja dan dapat menimpa siapa saja. Orang lain, teman dekat, keluarga ataupun kita sendiri dapat menjadi korbannya. Kejadian gawat darurat biasanya berlangsung cepat dan tiba-tiba sehingga sulit memprediksi kapan terjadinya.

Sri Siswati, 2013, Etika dan Hukum Kesehatan: Dalam Perspektif Undang-Undang Kesehatan, Rajawali Pers, Jakarta, Hal 33.
Langkah terbaik untuk situasi ini adalah waspada dan melakukan upaya konkrit untuk mengantisipasinya dan tentu harus dipikirkan satu bentuk mekanisme bantuan kepada korban dari awal tempat kejadian, selama perjalanan menuju sarana kesehatan, bantuan difasilitas kesehatan sampai pasca kejadian cedera.

Berdasarkan menurut Undang-undang Nomor 44 Tahun 2009 tentang Rumah Sakit dan Undang-undang Nomor 36 Tahun 2009 tentang Kesehatan sudah jelas mengatur bahwa dalam memberikan pelayanan kesehatan rumah sakit atau dokter yang bekerja di rumah sakit dapat memberikan pertolongan pertama kepada pasien yang dalam keadaan gawat darurat. Hal ini sesuai dengan Pasal 32 ayat (1) dan (2) Undang-undang Nomor 36 Tahun 2009 tentang Kesehatan, yang menentukan bahwa :

"Dalam keadaan darurat, fasilitas pelayanan kesehatan, baik pemerintah maupun swasta, wajib memberikan pelayanan kesehatan bagi penyelamatan nyawa pasien dan mencegah kecacatan terlebih dahulu".

Berdasarkan ketentuan di atas, maka pelayanan kesehatan di unit gawat darurat harus mendahulukan kepentingan dan keselamatan pasien dalam hal mencegah terjadinya kecacatan dan kematian bagi pasien kemudian dalam Pasal 1 ayat (2) dan Pasal 29 ayat (1) huruf c Undangundang Nomor 44 Tahun 2009 tentang Rumah Sakit, diperjelas lagi dengan :

"Gawat Darurat adalah klinis pasien yang membutuhkan tindakan medis segera guna penyelamatan nyawa dan pencegahan 
kecacatan lebih lanjut.Memberikan pelayanan gawat darurat kepada pasien sesuai dengan kemampuan pelayanan."

Dari 2 (dua) Pasal dalam Undang-Undang tersebut sangat jelaslah pengaturan tentang pelayanan kesehatan di unit gawat darurat sehingga setiap pasien membutuhkan pertolongan di unit gawat darurat dapat langsung ditangani oleh dokter atau tenaga kesehatan yang bekerja di rumah sakit. ${ }^{2}$ Informed consent pada kondisi kegawatan medik merupakan hal yang penting walaupun prioritasnya paling bawah. Hal terpenting adalah menyelamatkan nyawa atau menghindarkan organ tubuh dari kerusakan menetap, karena itu informed consent tidak boleh menjadi penghalang bagi pelaksanaan emergency care dan hal tersebut diperjelas lagi seperti yang tertuang pada Kode Etik Kedokteran pada Pasal 13 yang berbunyi sebagai berikut :

"Setiap dokter wajib melakukan pertolongan darurat sebagai suatu tugas perikemanusiaan, kecuali bila ia yakin ada orang lain bersedia dan mampu memberikannya."3

Pelayanan kesehatan Unit Gawat Darurat di Rumah Sakit Umum Daerah Abdul Wahab Sjahranie Samarinda tempat penulis bertempat tinggal dalam beberapa tahun terakhir ini sering terjadi permasalahan yang sering merugikan pihak tenaga kesehatan khususnya dokter dalam pelayanan kesehatan di unit gawat darurat. Menurut pengamatan penulis bahwa dari kurun waktu tahun 2012-2014 terjadi 5 kasus yang

2 Syahrul Machmud, 2008, Penegakan Hukum dan Perlindungan Hukum Bagi Dokter Yang Diduga Melakukan Medikal Malpraktek, Penerbit CV. Mandar Maju, Bandung, Hal 88.

3 As'ad Sungguh, 2014, Kode Etik Profesi Tentang Kesehatan, Sinar Grafika, Jakarta, Hal 5. menyebabkan terjadinya sengketa medik antara dokter dan pasien maupun keluarganya dengan berbagai macam penyebab baik yang menolak persetujuan tindakan medik hingga penanganan yang menyebabkan kecacatan ataupun kematian pada pasien.

\section{PERUMUSAN MASALAH}

Berdasarkan uraian tersebut dapat dirumuskan masalahnya adalah "Bagaimana Penerapan Perlindungan Hukum Bagi Dokter dan Penyelesaian Permasalahan Medis pada Pelayanan Kegawat Daruratan di Rumah Sakit Umum Daerah Abdul Wahab Sjahranie Samarinda.

\section{METODE PENELITIAN}

Metode pendekatan yang dipergunakan dalam penelitian ini adalah metode pendekatan yuridis normatif. ${ }^{4}$ Tipe penelitian ini digolongkan kepada tipe penelitian untuk menemukan hukum in concreto. ${ }^{5}$ Penelitian dilaksanakan di Perpustakaan Pascasarjana Fakultas Hukum Universitas Jenderal Soedirman dengan menelaah pustaka yang berkaitan dengan kajian penelitian dan Rumah Sakit Umum Daerah Abdul Wahab Sjahranie. Sumber data yang digunakan dalam penelitian adalah sumber data sekunder dalam hal ini menggunakan data hasil dokumentasi bagian medikolegal Rumah Sakit Umum Daerah Abdul Wahab Sjahranie Samarinda sedangkan bahan hukum primer dalam hal ini penulis menggunakan

\footnotetext{
$4 \quad$ Mukti Dewata F. N.\&Y. Achmad, 2010, Dualisme penelitian Normatif \& Empiris, Pustaka Pelajar, Yogyakarta, Hal. 53.

5 Ronny Hanintiyo Sumitro, 1990, Metodologi Penelitian Hukum dan Junimetri, Ghalia Indonesia, Jakarta, Hal. 12.
} 
Kitab Undang-Undang Hukum Perdata $(\mathrm{KUH}-$ Perdata), Undang-undang Nomor 29 Tahun 2004 tentang Praktik Kedokteran, Undang-undang Nomor 36 Tahun 2009 tentang Kesehatan, Undang-undang Nomor 44 Tahun 2009 tentang Rumah Sakit, Peraturan Menteri Kesehatan Republik Indonesia Nomor 290 Tahun 2008 tentang persetujuan tindakan kedokteran, Kode Etik Kedokteran Indonesia (Kodeki), Sumpah Dokter Indonesia.

\section{PEMBAHASAN}

Penerapan Perlindungan Hukum Bagi Dokter pada Pelayanan Kegawat Daruratan di Rumah Sakit Umum Abdul Wahab Sjahranie Samarinda.

Jika dilihat dari 5 (lima) kasus yang terjadi pada Rumah Sakit Umum Abdul Wahab Sjahranie dimana pihak yang terlibat disana yakni tenaga kesehatan yakni (dokter dan perawat), rumah sakit dan pasien maka bisa dilakukan analisis sebagai berikut :

1. Kasus pertama yang terjadi pada Tanggal 13 Februari 2012, merupakan salah satu kasus dimana masalah berawal atau berakar dari tindakan medis yang diberikan oleh tenaga kesehatan yakni dokter dan perawat yang mana mencoba untuk menyelamatkan nyawa pasien dari kondisi kritis ketika itunamun tidak dapat menolong nyawa pasien dan dengan memberikan penjelasan mengenai informasi tindakan medis yang telah dilakukan ketika keluarga pasien tiba di Rumah Sakit Umum Abdul Wahab Sjahranie tetapi tidak dapat diterima oleh pihak keluarga pasien khususnya paman pasien sehingga menuntut ganti rugi kepada pihak rumah sakit.Para dokter dalam hal ini yang bekerja telah sesuai dengan kewajibannya pada pelayanan kegawat daruratan dimana menjalankan standar profesi medis dan standard operasional procedur (SOP) yang berlaku di Unit Gawat Darurat Rumah Sakit Umum Daerah Abdul Wahab Sjahranie serta sudah bekerja sesuai menurut Undang-Undang Nomor 29 Tahun 2004 Tentang Praktik Kedokteran sebagai berikut :

Pasal 50

Dokter atau dokter gigi dalam melaksanakan praktik kedokteran mempunyai hak:

a) Memperoleh perlindungan hukum sepanjang melaksanakan tugas sesuai dengan standar profesi dan standar prosedur operasional; dan

Pasal 51

Dokter atau dokter gigi dalam melaksanakan praktik kedokteran mempunyaikewajiban :

a) Memberikan pelayanan medis sesuai dengan standar profesi dan standar prosedur operasional serta kebutuhan medis pasien;

Hal tersebut didukung pula oleh KODEKI (Kode Etik Kedokteran Indonesia) yakni:

a) Seorang dokter wajib melakukan pertolongan darurat sebagai suatu tugas kemanusiaan, kecuali bila yakin ada orang lain bersedia dan mampu memberikannya (Pasal 13).

b) Seorang dokter harus senantiasa berupaya melaksanakan profesinya sesuai dengan standar profesi yang tertinggi (Pasal 2).

c) Setiap dokter harus senantiasa mengingat akan kewajibannya melindungi hidup insani (Pasal 7d).

d) Setiap dokter wajib melakukan pertolongan darurat sebagai suatu tugas perikemanusiaan, kecuali bila ia yakin 
ada orang lain bersedia dan mampu memberikannya (ayat 14). ${ }^{6}$

Hal tersebut pun diperjelas melalui lafal Sumpah Dokter Indonesia yang berbunyi sebagai berikut : ${ }^{7}$

"Demi Allah saya bersumpah/ berjanji, bahwa :

1. Saya akan membaktikan hidup saya guna kepentingan perikemanusiaan;

2. Saya akan memelihara dengan sekuat tenaga martabat dan tradisi luhur jabatan kedokteran;

3. Saya akan menjalankan tugas saya dengan cara yang terhormat dan bersusila, sesuai dengan martabat perkerjaan saya sebagai dokter;

4. Saya akan menjalankan tugas saya dengan mengutamakan kepentingan masyarakat;

5. Saya akan merahasiakan segala sesuatu yang saya ketahui karena pekerjaan saya dan keilmuan saya sebagai dokter;

6. Saya akan mempergunakan pengetahuan kedokteran saya untuk sesuatu yang bertentangan dengan perikemanusiaan, sekalipun diancam;

7. Saya akan menghormati setiap hidup insane mulai dari saaat pembuahan;

8. Saya akan senantiasa mengutamakan kesehatan pasien;

9. Saya akan berikhtiar dengan sungguh-sungguh supaya saya tidak terpengaruh oleh pertimbangan keagaaman, kesukuan, perbedaa kelamin, politik kepartaian, atau kedudukan sosial dalam menunaikan kewajiban terhadap pasien;
10.Saya akan memberikan kepada guru-guru saya penghormatan dan pernyataan terima kasih yang selayaknya;

11.Saya akan memperlakukan teman sejawat saya sebagaimana saya sendiri ingin diperlakukan;

12.Saya akan menaati dan mengamalkan Kode Etik Kedokteran Indonesia;

13.Saya ikrarkan sumpah ini dengan sungguhsungguh dan dengan mempertaruhkan kehormatan diri saya.

Selain itu dalam kondisi kritis seperti pada kasus ini pasien tidak sadar maka tidak diperlukan lagi persetujuan tindakan medik (informed consent) yang justru akan menghambat bantuan tindakan medik yang akan diberikan kepada pasien karena hal tersebut sudah sesuai dengan Peraturan Menteri Kesehatan Nomor. 290 Tahun 2008 Pasal 4 Ayat(1) yang berbunyi :dalam keadaan gawat darurat, untuk menyelawatkan jiwa pasien dan/ atau mencegah kecacatan tidak diperlukan persetujuan tindakan kedokteran. Dalam hal ini pun pihak rumah sakit telah melakukan tindakan usaha yang tepat melalui tenaga kesehatannya (dokter dan perawat) dimana sesuai dengan Undangundang Nomor 36 tahun 2009 tentang kesehatan, Pasal 32 ayat (1) yang berbunyi: dalam keadaan darurat, fasilitas pelayanan kesehatan, baik pemerintah maupun swasta, wajib memberikan pelayanan kesehatan bagi penyelamatan nyawa pasien dan mencegah kecacatan terlebih dahulu.

Pihak rumah sakit dalam hal ini pun ikut membantu dalam pengupayaan penyelesaian masalah dengan turut serta memberikan perlindungan hukum dikarenakan dokter pun merupakan

Lafal Sumpah Dokter Indonesia. 
tenaga kesehatan yang bernaung dalam institusi Rumah Sakit Abdul Wahab Sjahranie sehingga sudah kewajiban rumah sakit tersebut untuk membantu dokternya yang sudah bekerja memberikan pelayanan medis sesuai standar profesi dan standar operasional prosedur (SOP) yang berlaku di rumah sakit tersebut. Oleh karena itu dalam hal ini perlindungan hukum yang diberikan oleh pihak Rumah Sakit kepada dokternya yang bekerja di Rumah Sakit Umum Abdul Wahab Sjahranie tersebut sudah sesuai jika dilihat dalam Undang-undang Nomor 44 Tahun 2009 tentang Rumah Sakit dalam Pasal 29 Ayat (1) point (s) yang menyatakan bahwa : Melindungi dan memberikan bantuan hukum bagi semua petugas Rumah Sakit dalam melaksanakan tugas.

2. Kasus kedua yang terjadi Tanggal 24 September pada tahun yang sama (2012), kasus yang terjadi dimana berasal muasal dari ketidaksetujuan pihak keluarga pasien terhadap tindakan medik yang dilakukan oleh pihak dokter yang bekerja di UGD dan ICU Rumah Sakit Umum Abdul Wahab Sjahranie kepada pasien yang ditunjukkan ketika datang ke Rumah Sakit Umum Abdul Wahab Sjahranie sehingga menimbulkan tuntutan ganti kerugian kepada pihak rumah sakit. Dalam hal ini pun posisi pihak dokter dan rumah sakit tidak pula sepatutnya dapat dipersalahkan karena apa yang telah dokter UGD dan ICU serta pihak rumah sakit lakukan tersebut telah sesuai dengan Undang-Undang Nomor 29 Tahun 2004 Tentang Praktik Kedokteran dalam Pasal 50-51 butir (a) dan Peraturan Menteri Kesehatan Nomor. 290 Tahun 2008 Pasal 4 Ayat(1) tentang persetujuan tindakan medik serta Undang-undang Nomor 36 tahun 2009 tentang kesehatan, Pasal 32 ayat (1).

Hal ini pun didukung oleh doktrin Good samaritan law yang menjamin kepada setiap tindakan medik dokter atau tenaga kesehatan dalam menjalankan tugas dan fungsinya dalam keadaan darurat dengan tidak melewati batas yang digariskan dalam doktrin tersebut antara lain :

a. Kesukarelaan pihak penolong.

b. Itikad baik pihak penolong.

Di Amerika penerapan doktrin Good Samaritan dalam peraturan perundang-undangan pada hampir seluruh negara bagian.Doktrin tersebut terutama diberlakukan dalam fase prarumah sakit untuk melindungi pihak yang secara sukarela beritikad baik menolong seseorang dalam keadaan gawat darurat. Dengan demikian seorang pasien dilarang menggugat dokter atau tenaga kesehatan lain untuk kecederaan yang dialaminya. Dasar teori ini adalah memberikan kesamaan hak serta menegakkan dasar moral secara universal sehingga dalam memberikan bantuan atau pertolongan kepada seseorang yang menderita dengan tidak memperhatikan materi. Baik negaranegara mengadopsi Code Napoleon dan maupun negara yang mengadopsi sistem hukum Common Law mereka juga mengadopsi teori good samaritan law ini sebagai bagian dasar penegakan hukum di negaranya. ${ }^{8}$ 
3. Kasus yang ketiga yang terjadi pada tahun yang berbeda dari kasus-kasus yang sebelumnya yakni Tanggal 28 Juni 2013, kali ini kasus bermula ketika pihak keluarga pasien tidak dapat menerima kondisi atau keadaan pasien yang kembali masuk ke rumah sakit yang sama seperti sebelumnya yakni Rumah Sakit Umum Abdul Wahab Sjahranie dengan penyakit komplikasi kencing manis yang ternyata telah dimiliki sejak lama oleh pasien namun tidak diketahui sewaktu dulu pertama kali masuk ke Rumah Sakit Abdul Wahab Sjahranie. Sebenarnya hal (kondisi/keadaan) tersebut telah coba dikonfirmasi dan ditanyakan kepada petugas (perawat) puskesmas yang merujuk pasien namun tidak didapatkan dan demi keselamatan pasien yang keadaannya dapat semakin buruk setiap saat maka dokter segera mengambil tindakan medik dengan mengoperasi pasien. Dalam hal ini pun pihak dokter dan rumah sakit tidak seharusnya dipersalahkan oleh pihak keluarga pasien karena dokter telah melakukan semua tindakan medik yang diperlukan menurut standar profesi dan SOP (Standard Operational Procedure) menurutUndang-Undang Nomor 29 Tahun 2004 Tentang Praktik Kedokteran dalam Pasal 50-51 butir (a). Pihak rumah sakit juga sudah melakukan apa yang mereka harus lakukan sesuai dengan Undang-undang Nomor 36 tahun 2009 tentang kesehatan, Pasal 32 ayat (1) serta melakukan persetujuan tindakan medik baik tertulis dan lisan yang telah sesuai Pasal 45 Undang-undang Nomor 29 Tahun 2004 tentang Praktik Kedokteran yang berbunyi:
Pasal 45 ayat (1): Setiap tindakan kedokteran atau kedokteran gigi yang akan dilakukan oleh dokter atau dokter gigi terhadap pasien harus mendapat persetujuan.

Pasal 45 ayat (2) : Persetujuan sebagaimana dimaksud pada ayat (1) diberikan setelah pasien mendapat penjelasan secara lengkap.

Pasal 45 ayat (3) : Penjelasan sebagaimana dimaksud pada ayat (2) sekurang-kurangnya mencakup :

a. Diagnosis dan tata cara tindakan medis;

b. Tujuan tindakan medis yang dilakukan;

c. Alternatif tindakan lain dan risikonya;

d. Risiko dan komplikasi yang mungkin terjadi; dan

e. Prognosis terhadap tindakan yang dilakukan.

Pasal 45 ayat (4) : Persetujuan sebagaimana dimaksud pada ayat (2) dapat diberikan baik secara tertulis maupun lisan.

Pasal 45 ayat (5) : Setiap tindakan kedokteran atau kedokteran gigi yang mengandung risiko tinggi harus diberikan dengan persetujuan tertulis yang ditandatangani oleh yang berhak memberikan persetujuan.

Pasal 45 ayat (6) : Ketentuan mengenai tata cara persetujuan tindakan kedokteran atau kedokteran gigi sebagaimana dimaksud pada ayat (1), ayat (2), ayat (30), ayat (4) dan ayat (5) diatur dengan Peraturan Menteri.

Selain itu pemberian penjelasan (informasi) disertai persetujuan tindakan medik juga terdapat pada Ketentuan Pasal 17 Peraturan Menteri Kesehatan Nomor. 1419 Tahun 2005 tentang Penyelenggaraan Praktek Dokter dan Dokter Gigi, disebutkan bahwa dokter memberi 
penjelasan kepada pasien tentang tindakan kedokteran yang akan dilakukan sebelum melakukan tindakan tersebut.

4. Kasus yang keempat yang terjadi pada Tanggal 2 November di tahun yang sama (2013), kasus ini terjadi berasal dari rasa ketidakpuasan terhadap penanganan yang dilakukan tenaga kesehatan khususnya dokter di Unit Gawat Darurat Rumah Sakit Umum Abdul Wahab Sjahranie kepada pasien yang di diagnosis serangan jantung (infark miokard) sehingga pasien pun akhirnya meninggal padahal sebelum kondisi itu terjadi dokter telah mengusahakan tindakan medik yang telah sesuai dengan SOP (standard operational procedure) dan standar profesi yang berlaku di Unit Gawat Darurat Rumah Sakit Umum Abdul Wahab Sjahranie serta Undang-Undang Nomor 29 Tahun 2004 Tentang Praktik Kedokteran dalam Pasal 50-51 butir (a).Pihak rumah sakit juga sudah melakukan apa yang mereka harus lakukan sesuai dengan Undang-undang Nomor 36 tahun 2009 tentang kesehatan, Pasal 32 ayat (1) serta melakukan persetujuan tindakan medik baik tertulis dan lisan yang telah sesuai Pasal 45 Undang-undang Nomor 29 Tahun 2004 tentang Praktik Kedokteran sebelum kondisi pasien memburuk dan meninggal.

Dalam Pasal 1354 KUHPerdata, pengertian zaakwarneming adalah mengambil alih tanggung jawab dari seseorang sampai yang bersangkutan sanggup lagi untuk mengurus dirinya sendiri. Pasal 1354 KUHPerdata selengkapnya berbunyi :Jika seseorang dengan sukarela, dengan tidak mendapat perintah untuk itu, mewakili urusan orang lain dengan atau tanpa pengetahuan orang lain, maka ia secara diam-diam mengikat dirinya untuk meneruskan serta menyelesaikan urusan tersebut, hingga orang yang diwakili kepentingannya dapat mengerjakan sendiri urusan itu. la memikul segala kewajiban yang harus dipikulnya, seandainya ia kuasakan dengan suatu pemberian kuasa yang dinyatakan dengan tegas. Dalam keadaan demikian, perikatan yang timbul tidak berdasarkan suatu persetujuan pasien, tetapi berdasarkan suatu perbuatan menurut hukum, yaitu : dokter berkewajiban mengurus kepentingan pasien sebaik-baiknya setelah pasien sadar kembali, dokter berkewajiban memberikan informasi mengenai tindakan medis yang telah dilakukannya dan mengenai tindakan medis yang telah dilakukannya dan mengenai segala kemungkinan yang timbul dari tindakan tersebut. Untuk tindakan selanjutnya tergantung pada persetujuan pasien yang bersangkutan.

Hal ini pun sebenarnya telah sesuai dengan teori yang dipakai sebagai alasan tindakan dokter tersebut adalah pendapat dari Leenen yang mengemukakan suatu konstruksi hukum yang disebut "Fiksi Hukum" dimana seseorang dalam keadaan tidak sadar akan menyetujui apa yang ada pada umumnya disetujui oleh para pasien yang berada dalam situasi dan kondisi yang sama. Oleh karena itu dalam hal ini pihak keluarga seharusnya menghormati keinginan atau hak asasi pasien yang telah membuat keputusan akan kese- 
hatan yang dimiliki oleh dirinya sendiri sebelumnya (autonomy). ${ }^{9}$

5. Kasus yang kelima terjadi pada Tanggal 17 Maret 2014, masalah yang terjadi dikarenakan pihak keluarga khususnya menantu pasien tidak dapat menerima begitu saja kematian pasien sehingga berusaha untuk menuntut ganti rugi kepada pihak dokter dan rumah sakit. Kali ini pihak dokter kembali dipersalahkan oleh karena tidak dapat menolong nyawa pasien yang memang menurut kondisi maupun keadaan medisnya sendiri sangatlah sukar untuk tertolong karena letak gumpalan darah stroke yang mengakibatkan pasien mengalami penurunan kesadaran berada di daerah medula oblongata (batang otak). Namun diluar hal tersebut pihak dokter sendiri sudah mengupayakan sesuai kewajibannya yakni dengan melakukan tindakan-tindakan medik agar menolong pasien seperti pemberian defibrilasi, RJP (resusitasi jantung paru), ET (endotracheal tube) dan obat-obatan kegawatdaruratan tetapi hal tersebut tetap tidak dapat membantu sehingga pasien meninggal. Usaha medik yang dilakukan dokter jaga UGD tersebut tidaklah salah karena telah sesuai dengan Undang-Undang Nomor 29 Tahun 2004 Tentang Praktik Kedokteran dalam Pasal 50-51 butir (a). Selain itu dokter tersebut juga telah melakukan informed consent kepada keluarga pasienyang mana telah sesuai pula dengan Pasal 45 Undang-undang Nomor 29 Tahun 2004 tentang Praktik Kedokteran.

9 Veronica, Komalawati, 2002, Peranan Informed Consent dalam Transaksi Terapeutik (persetujuan dalam Hubungan
Kesimpulan dari 5 (lima) kasus diatas penerapan perlindungan hukum di bagi dokter pada pelayanan kegawat daruratan di Rumah Sakit Abdul Wahab Sjahranie sudah sesuai menurut Undang-Undang Nomor 29 Tahun 2004 Tentang Praktik Kedokteran dimana dalam Pasal 50-51 butir (a), Pasal 45 Undang-undang Nomor 29 Tahun 2004 tentang Praktik Kedokteran, Undangundang Nomor 36 tahun 2009 tentang kesehatan, Pasal 32 ayat (1) dan Undang-undang Nomor 44 Tahun 2009 tentang Rumah Sakit dalam Pasal 29 Ayat (1) point (s) maka apabila dokter dan rumah sakit tersebut telah melakukan apa yang telah sesuai dengan perundang-undangan dan peraturan yang ada yang saat ini berlaku di Indonesia mereka pun tidak patut untuk dipersalahkan dan terbebas dari ganti kerugian. Persetujuan tindakan medik bagi pasien yang berada di unit gawat darurat tentunya berbeda dengan pasien yang pada umumnya, seorang pasien yang dalam keadaan darurat jika sudah berada di rumah sakit maka persetujuan tindakan medik dapat diabaikan.Persetujuan tindakan medik dapat dilakukan ketika pasien sudah sadar atau keluarga pasien sudah berada di tempat.

\section{Penyelesaian Permasalahan Medis pada Pelayanan Kegawat Daruratan di Rumah Sakit Umum Abdul Wahab Sjahranie Samarinda.}

Menurut hasil dari penelitian yang telah dilakukan di Unit Gawat Darurat Rumah Sakit Umum Abdul Wahab Sjahranie analisis Bakti, Bandung, Hal 87. 
penyelesaian masalah (sengketa) medis sebagai berikut :

1. Pada kasus pertama yang terjadi pada Tanggal 13 Februari 2012, pihak Rumah Sakit dan Dokter Rumah Sakit Umum Abdul Wahab Sjahranie menempuh atau melalui yakni mediasi jalur non-litigasi (di luar pengadilan) daripada menggunakan jalur litigasi (melalui pengadilan) dengan pihak keluarga pasien sehingga mau tidak mau maka dalam kasus ini dilakukan penunjukkan khusus seorang mediator dari luar para pihak yang bermasalah (bersengketa) meskipun akan berakibat biaya yang dikeluarkan menjadi mahal karena sangat sulit mencari seorang yang ahli dan memiliki pengetahuan tentang permasalahan medis saat itu namun hal tersebut tetap dilakukan agar permasalahan yang ada segera dapat diselesaikan. Selain itu alasan lain mengapa lebih memilih mediasi daripada penyelesaian sengketa lain bahwa mediasi merupakan salah satu cara penyelesaian sengketa alternatif yang telah di khususkan pada permasalahan (sengketa) medis antara dokter, rumah sakit dan pasien yang terdapat dalam Undang-undang Nomor 36 Tahun 2009 tentang kesehatan, Pasal 29yang berbunyi : "Dalam hal tenaga kesehatan diduga melakukan kelalaian dalam menjalankan profesinya, kelalaian tersebut harus diselesaikan terlebih dahulu melalui mediasi". Oleh karena itu hal ini pun diambil sebagai langkah terbaik bagi pihak-pihak yang terlibat dikarenakan sebab-sebab tertentu seperti penyelesaiannya bersifat tertutup diantara pihak-pihak yang terlibat saja dan jauh dari pemberitaan media massa serta bagi pihak keluarga pasien jalur mediasi ini merupakan solusi sebagai upaya ganti rugi dari uang yang mereka keluarkan selama masa perawatan di rumah sakit dan juga santunan bagi anggota keluarga pasien yang masih hidup. Selain itu Peraturan Mahkamah Agung Nomor 1 tahun 2008 tentang Prosedur mediasi di pengadilan pada Pasal 4 juga memberikan penekanan pada penyelesaian sengketa melalui proses mediasi yaitu “.....semua sengketa perdata yang diajukan ke pengadilan wajib lebih dahulu diupayakan penyelesaian melalui perdamaian dengan bantuan mediator". Begitu juga bila sengketa itu terjadi di institusi rumah sakit berdasarkan Undang Undang Nomor 44 tahun 2009 tentang rumah sakit Pasal 60 huruf (f) mewajibkan pada Badan Pengawas Rumah Sakit untuk menerima pengaduan dan melakukan upaya penyelesaian sengketa dengan cara mediasi.

2. Pada kasus kedua yang terjadi pada Tanggal 24 September 2012 atau di tahun yang sama dengan kasus pertama pun pihak Rumah Sakit dan Dokter Rumah Sakit Umum Abdul Wahab Sjahranie menggunakan cara atau metode yang sama yakni mediasi di luar pengadilan (non-litigasi) dikarenakan merupakan perintah perundang-undangan dan peraturan hukum yang berlaku di Indonesia kemudian kelebihan dari mediasi yang lain yaitu bersifat tertutup dan rahasia selain itu mediasi tidak melibatkan pihak penegak hukum (litigasi) seperti hakim (pengadilan). 
3. Pada kasus ketiga yang terjadi pada Tanggal 28 Juni 2013, pihak Rumah Sakit dan Dokter Rumah Sakit Umum Abdul Wahab Sjahranie menempuh cara atau jalur yang sama pula seperti pada awal kasus sebelumnya namunkali ini sedikit berbeda dari sebelumnya dikarenakan mediasi yang coba dilakukan sebelumnya melalui jalur non-litigasi (diluar pengadilan) tidak mencapai kesepakatan karena beberapa sebab seperti pihak keluarga pasien berhalangan hadir, pihak dokter dan rumah sakit tidak sepakat beban ganti rugi yang diminta terlalu tinggi dan lainlain. Perihal tentang mediasi yang dilakukan adalah menggali kehendak Undang-Undang (Pasal 30 HIR / Pasal 154 R.Bg). Akhirnya permasalahan (sengketa) medis harus diselesaikan di Pengadilan Negeri (PN) setempat (Tingkat Pertama) dengan penunjukkan seorang hakim oleh ketua pengadilan yang bertugas sebagai mediator agar memfasilitasi penyelesaian sengketa medis antara pihak dokter, rumah sakit dan keluarga pasien sehingga pada kasus sengketa medis kali ini membutuhkan waktu yang lama (berlarut-larut) dan biaya yang dikeluarkan pun menjadi bengkak (banyak). Sifat Mediasi di pengadilan sebagai berikut $:^{10}$

a. Wajib (Mandatory) atas seluruh perkara perdata yang diajukan kepengadilan Tingkat Pertama.

b. Hakim mewajibkan para pihak menempuh lebih dahulu proses mediasi; c. Hakim wajib memunda siadang dan memberikan kesempatan para pihak untuk mediasi;

d. Hakim wajib memberikan penjelasan ttg prosedur mediasi dan biayanya;

e. Apabila para pihak diwakili Penasehat Hukum maka setriap keputusan yang diambil harus memperoleh persetujuan tertulis dari para pihak;

f. Proses mediasi pada dasarnya tidak bersifat terbuka untu umum, kecuali para pihak menghendaki lain, sedangkan mediasi untuk kepentingan publik terbuka untuk umum.

Hak memilih mediator oleh para pihak :

1) Mediator ditunjuk (disepakati) oleh para pihak, dapat dari dalam peradilan (hakim) yang sudah mendapat sertifikat sebagai mediator, atau pihak dari luar pengadilan yang sudah bersetrifikat;

2) Jika para pihak dapat sepakat dalam memilih mediator maka ketua majelis hakim dapat menetapkan menunjuk mediator yang terdaftar dalam PN tersebut;

3) Waktu paling lama satu hari kerja setelah sidang pertama;

4) Ketua atau anggota majelis hakim di larang sebagai mediator.

Kewajiban Mediator :

1. Mediator wajib menyusin jadwal mediasi;

2. Mediator wajib mendorong dan menelurusi serta mengali kepentingan para pihak;

3. Mediator wajib mencari berbagi pilihan penyelesain; 
4. Mediator wajib merumuskan kesepakatan secara tertulis;

5. Mediator wajib memuat klausa pencabutan perkara;

6. Mediator wajib memeriksa kesepakan untuk menghindari jika ada klausa yang bertentangam dengan hukum;

7. Setelah 22 hari melalui mediasi tidak berhasil, maka mediator wajib menyatakan secara tertulis bagwa mediasi telah gagal dan memberikan pemberitahuan kepada majelis hakim;

8. Jika mediasi gagal, maka semua fotokopi, notulen, catatan mediator wajib dimusnahkan.

Waktu dan Tempat Mediasi :

a) Paling lama 30 hari, bagi mediator di luar Pengadilan Negeri dapat di perpanjang;

b) 22 hari setelah ditunjuknya mediator;

c) 7 hari setelah mediator ditunjuk para pihak wajib menyerahkan fotokopi dokumen perkara (duduk perkara, surat-surat, dan lain-lain );

d) Mediasi dapat diselengarakan disalah satu ruangan pengadilan atau tempat lain yang disepakati para pihak

4. Pada kasus keempat yang terjadi pada Tanggal 2 November 2013 atau pada tahun yang sama, pihak Rumah Sakit dan Dokter Rumah Sakit Umum Abdul Wahab Sjahranie tetap menggunakan cara yang sama yaitu mediasi melalui jalur luar pengadilan (nonlitigasi) bukan melalui mediasi pengadilan (litigasi). Mediasi kembali digunakan dalam hal ini dikarenakan hasil yang dicapai yakni win-win solution atau pihak-pihak yang bermasalah tersebut memperoleh keuntungan yang sama sehingga tidak ada yang merasa dirugikan (menang/kalah). Selain itu efek positif yang dapat diperoleh dari jalur mediasi adalah hubungan dokter pasien akan tetap senantiasa terjaga dengan baik

5. Pada kasus kelima yang terjadi padaTanggal 17 Maret2014, pihak Rumah Sakit dan Dokter Rumah Sakit Umum Abdul Wahab Sjahranie kembali menggunakan jalur atau cara yang sama seperti kasus-kasus pada tahun sebelumnya yaitu mediasi luar pengadilan (non-litigasi) dikarenakan memang telah sesuai dengan perundang-undangan dan peraturan yang belaku di Indonesia. Selain itu penggunaan kembali mediasi luar pengadilan disebabkan sudah lebih berpengalaman dan terbiasa karena kasus-kasus sengketa medis sebelumnya yang juga diselesaikan dengan cara yang sama.

Kesimpulan yang dapat diambil dari analisis penyelesaian masalah 5 (lima) kasus yang terjadi di Unit Gawat Darurat Rumah Umum Sakit Abdul Wahab Sjahranie diatas adalah penyelesaian masalah yang terjadi diantara pihak dokter, rumah sakit dan keluarga pasien dengan menggunakan jalur atau cara mediasi baik itu melalui pengadilan (litigasi) maupun (non-litigasi) dikarenakan proses mediasi merupakan salah satu cara untuk menyelesaikan sengketa medis yang telah diatur dalam Undang-undang Nomor 36 tahun 2009 tentang kesehatan, Pasal 29 yang berbunyi : "Dalam hal tenaga kesehatan diduga melakukan kelalaian dalam menjalankan profesinya, kelalaian tersebut harus diselesaikan terlebih dahulu melalui mediasi" dan sejalan dengan undang-undang tersebut Peraturan Mahkamah Agung Nomor 1 tahun 2008 tentang Prosedur mediasi di pengadilan pada Pasal 4 juga memberikan penekanan pada penyelesaian 
sengketa melalui proses mediasi yaitu "....semua sengketa perdata yang diajukan ke pengadilan wajib lebih dahulu diupayakan penyelesaian melalui perdamaian dengan bantuan mediator".

\section{PENUTUP}

\section{Simpulan}

Pertama, Penerapan perlindungan hukum bagi dokter pada pelayanan kegawat daruratan di Rumah Sakit Umum Abdul Wahab Sjahranie sudah sesuai menurut perundang-undangan dan peraturan yang berlaku saat ini di Indonesia sehingga bagi dokter pada pelayanan kegawat daruratan yang telah melakukan tindakan medik yang sesuai dengan standar profesi dan standar operational procedure (SOP) maka tidak patut untuk dipersalahkan.

Kedua, penyelesaian Sengketa medis pada pelayanan kegawat daruratan di Rumah Sakit Umum Abdul Wahab Sjahranie menggunakan proses mediasi yang termasuk dalam Alternative Dispute Resolution (ADR) dikarenakan menurut Undang- undang Nomor 36 Tahun 2009 tentang Kesehatan Pasal 29 yang menyatakan bahwa dalam hal tenaga kesehatan diduga melakukan kelalaian dalam menjalankan profesinya, kelalaian tersebut harus diselesaikan terlebih dahulu melalui mediasi. Proses mediasi yang dipergunakan adalah mediasi diluar pengadilan (non-litigasi) yang menggunakan seorang mediator dan melalui pengadilan (litigasi) yang menggunakan seorang hakim yang ditunjukoleh ketua pengadilan negeri setempat (tingkat pertama) berdasarkan Pasal 30 HIR/154 RBg. Selain itu mediasi memiliki kelebihan sangat efisien dalam hal waktu dan biaya, lebih rahasia (tertutup), serta para pihak memperoleh hasil win-win solution.

Saran

Berdasarkan pada uraian hasil penelitian dan pembahasan maka diharapkan Rumah Sakit Umum Daerah Abdul Wahab Sjahranie untuk menyelenggarakan kegiatan penyuluhan secara berkala mengenai pemahaman tentang hak dan kewajiban pasien/keluarga pasien agar dapat mencegah dan meminimalisasi tuntutan-tuntutan/ ketidak puasan dari pasien/ keluarga pasien di masa yang akan datang.

\section{DAFTAR PUSTAKA}

Komalawati, Veronica, 2002. Peranan Informed Consent dalam Transaksi Terapeutik (persetujuan dalam Hubungan Dokter dan Pasien) Suatu Tinjauan Yuridis. Bandung ; PT. Citra Aditya Bakti.

Machmud, Syahrul, 2008, Penegakan Hukum dan Perlindungan Hukum Bagi Dokter Yang Diduga Melakukan Medikal Malpraktek, Penerbit CV. Mandar Maju, Bandung.

Mancini, MR, Gale AT. 1981. Emergency Care and The Law, Maryland :Aspen Publication

Mukti Dewata F. N.\&Y. Achmad. 2010. Dualisme penelitian Normatif \& Empiris. Yogyakarta.Pustaka Pelajar,

Siswati, Sri. 2013. Etika dan Hukum Kesehatan : Dalam Perspektif Undang-Undang Kesehatan. Jakarta : Rajawali Pers.

Sumitro, Ronny Hanintyo. 1990. Metodologi Penelitian Hukum dan Junimetri. Jakarta. Ghalia Indonesia.

Sungguh, As'ad. 2014. Kode Etik Profesi Tentang Kesehatan. Jakarta : Sinar Grafika.

Triwibowo, Cecep. 2014. Etika \& Hukum Kesehatan. Yogyakarta : Nuha Medika. 